Vol. 3, No. 1, Januari 2019, 99-104

Available Online at https://ejournal.warmadewa.ac.id/index.php/kulturistik DOI: dx.doi.org/10.22225/kulturistik.3.1.954

\title{
PEMAKAIAN BAHASA INDONESIA (KATA) DALAM SURAT RESMI/DINAS KELUAR DESA KESIMAN KERTALANGU KECAMATAN DENPASAR TIMUR DENPASAR (STUDI KASUS)
}

\author{
I Nengah Mileh \\ Universitas Warmadewa \\ milehmenuri@gmail.com
}

\begin{abstract}
ABSTRAK
Penelitian ini berjudul "Pemakaian Bahasa Indonesia (Kata) dalam Surat Resmi/Dinas keluar Desa Kesiman Kertalangu, kecamatan Denpasar Timur, Denpasar". Pemakaian bahasa Indonesia, khususnya pemakaian kata dalam surat resmi/dinas keluar Desa Kesiman Kertalangu, kecamatan Denpasar Timur Denpasar, masih ditemukan beberapa kesalahan. Dalam penelitian ini, yang menjadi objek kajian, yaitu mengenai kesalahan pemakaian kata. Metode observasi dan teknik catat digunakan dalam pengumpulan data, metode kualitatif deskriptif sinkronis digunakan untuk menganalisis data dibantu dengan teknik induktif atau deduktif, sedangkan metode informal digunakan untuk penyajian hasil. Dalam penelitian ini ditemukan beberapa jenis kesalahan pemakaian kata. Jenis kesalahan pemakaian kata meliputi: 1) penulisan kata depan, 2) penulisan kata yang hiperkorek, dan 3) pemakaian kata yang tidak tepat.
\end{abstract}

Kata kunci: surat, komunikasi, kata

\begin{abstract}
[The Use of Indonesian Language (Word) in the Official Letter / Outgoing Mail of Kesiman Kertalagu Village, East Denpasar Sub District, Denpasar] This research entitled "The Use of Indonesian Language (Word) in the Official Letter / Outgoing Mail of Kesiman Kertalangu Village, East Denpasar Sub District, Denpasar". The use of Indonesian, especially the use of the word in the official / official letter out of Kesiman Kertalangu Village, Denpasar Timur Sub-district, Denpasar, still found some errors. In this study, which is the object of study, namely regarding the misuse of the word. Observation methods and note-taking techniques are used in data collection, descriptive synchronic qualitative methods are used to analyze data aided by inductive or deductive techniques, while informal methods are used to present results. In this study found several types of word usage errors. The types of word usage errors include: 1) preposition writing, 2) hypercorrect word writing, and 3) improper use of words.
\end{abstract}

Keywords: letter, communication, word

\section{PENDAHULUAN}

Surat-menyurat merupakan salah satu kegiatan berbahasa yang dilakukan dalam komunikasi tertulis. Surat merupakan suatu alat untuk menyampaikan informasi tertulis pada pihak kedua. hal yang disampaikan itu dapat berupa, pernyataan, perminataan, laporan, dan sebagainya. Sebagai media komunikasi tertulis, surat memiliki kelebihan dibandingkan dengan alat komunikasi lainnya. Dikatakan demikian, karena surat menjadi bukti sah di atas hitam putih dan dapat 
menyampaikan sesuatu sesuai dengan keinginan penulisnya dengan biaya terjangkau.

Di samping itu, surat sebagai sarana komunikasi resmi memiliki beberapa fungsi antara lain (1) sebagai alat bukti tertulis, terutama surat-surat perjanjian, (2) sebagai alat pengingat karena memudahkan pengecekan ualng. (3) sebagai bukti historis misalnya surat tentang perubahan dan atau perkembangan instansi tertentu, (4) sebagai pedoman kerja, seperti surat keputusan dan surat perintah, (5) sebagai wakil penulis untuk berhadapan dengan lawan bicaranya, dan (6) sebagai jaminan keamanan, misalnya surat jalan (Arifin \& Dkk, 1987: 12).

Informasi yang ingin disampaikan oleh pengirim surat akan sampai kepada penerima surat kalau bahasa suratnya dan benar. Oleh karena itu, setiap pengonsep surat resmi dituntut untuk terampil berbahasa Indonesia yang benar di dalam surat yang ditulisnya. Keterampilan menggunakan bahasa Indonesia yang benar dalam surat resmi tidaklah gampang. Untuk terampil berbahasa Indonesia, banyak hal yang perlu dipahami, ditaati, dan dilakukan terkait dengan kaidah kebahasaan.

Dari uraian pada latar belakang di atas, ada satu masalah yang akan dikaji pada pemakaian bahasa Indonesia dalam surat resmi/dinas keluar desa Kesiman Kertalangu, kecamatan Denpasar Timur, Denpasar. Penelitian ini berfokus pada pemakaian kata dalam surat/dinas keluar desa Kesiman Kertalangu, kecamatan Denpasar Timur, Denpasar

\section{METODE}

Metode penelitian dibedakan atas tiga, yaitu (1) metode pengumpulan data, (2) metode analisis data, dan (3) penyajian hasil analisis serta dibantu dengan teknik tertentu.

Pengumpulan data dalam penelitian ini dilakukan dengan metode simak/ observasi (Sudaryanto, 1993: 41). Metode simak tersebut dibantu dengan teknik catat. Setiap data diperoleh dicatat secara ortografis dalam sebuah buku catatan yang telah disiapkan terlebih dahulu.

Data diperoleh dengan cara menyimak pemakaian bahasa Indonesia pada surat resmi/dinas keluar Desa Kesiman Kertalangu, Denpasar timur. Dalam penelitian ini surat yang dijadikan sampel penelitian adalah surat keluar pada bulan Mei dan Juni 2017. Jumlah surat keluar pada Mei 2017 sebanyak 6 surat dan pada Juni 2017 sebanyak 13 surat. Mengingat jumlah surat keluar tidak terlalu banyak maka semua surat keluar pada Mei dan Juni 2017 dijadikan sampel penelitian.

Penelitian ini bersifat sinkronis artinya sumber data diambil dari surat-surat resmi ke- luar Desa Kesiman Kertalangu, Denpasar timur bersifat kekinian (tahun 2017). Dengan demikian, metode yang dipakai dalam menganalisis data yang ada, yaitu metode deskriptif sinkronis.

Teknik analisis yang digunakan ialah teknik induktif dan teknik deduktif (Hadi, 1973: 44). Teknik induktif adalah pemaparan data yang bersifat khusus, kemudian dilanjutkan dengan suatu simpulan yang bersifat umum sedangkan teknik deduktif merupakan kebalikan dari teknik induktif.

Hasil analisis disajikan dengan metode informal. Metode informal merupakan suatu cara penyajian analisis atau kaidah dengan uraian atau rangkaian kata sedangkan metode formal merupakan cara penyajian hasil analisis atau kaidah dengan menggunakan tanda atau lambang (Sudaryanto, 1986: 62). 
Vol. 3, No. 1, Januari 2019, 101

Available Online at https://ejournal.warmadewa.ac.id/index.php/kulturistik DOI: dx.doi.org/10.22225/kulturistik.3.1.954

Teknik penyajian yang dipakai pada umumnya menggunakan teknik induktif, yaitu suatu jenis penyajian dengan cara mengemukakan sesuatu yang bersifat khusus lalu ditarik simpulan yang bersifat umum (Hadi, 1973). Akan tetapi, sekali-sekali juga digunakan cara lain, seperti teknik deduktif.

\section{PEMBAHASAN}

Pada bab ini diuraikan secara rinci mengenai kesalahan pemakaian kata serta perbaikannya sesuai dengan pemakaian kata yang mengacu pada Ejaan Bahasa Indonesia dan Kamus Besar Bahasa Indonesia.

\section{Kesalahan Pemakaian Kata}

Pada subbab ini dianalisis kesalahan pemakaian kata yang ditemukan di dalam surat resmi/dinas keluar desa Kesiman Kertalangu Denpasar Timur. Sebelum sampai pada analisis masalah pokok, terlebih dahulu dijelaskan pengertian beberapa hal yang berkaitan dengan permasalahan.

Analisis kesalahan pemakaian kata berarti menyelidiki tentang kekeliruan pemakaian kata, untuk mengetahui mengapa kata itu salah, apa jenis kesalahannya, dan bagaimana pemakaiannya yang betul. Semuanya itu, perlu dijelaskan dan diuraikan kaidah-kaidah bahasa yang berlaku dan relevan dengan mesalah yang dianalisis.

Tepat, saksama, dan lazim merupakan pedoman untuk memilih kata. Kata yang dipakai harus tepat, maksudnya kata tersebut harus mengandung arti yang jelas tidak menimbulkan makna ganda bagi pembaca. Kata yang saksama adalah kata yang serasi benar dengan apa yang dituturkan. Misalnya, jika yang dimaksud itu "diharuskan datang" jangan dikatan "diharapkan datang". Kata yang lazim, yaitu kata yang sudah dikenal oleh umum dan dipakai dalam bahasa Indonesia umum (Poerwadarminta, 1976).

Kata yang tepat, saksama, dan lazim termasuk kata yang sesuai dan benar. Selanjutnya, kata yang sesuai dan benar inilah yang dijadikan patokan dalam menganalisis kesalahan pemakaian kata di dalam surat resmi/dinas keluar desa Kesiman Kertalangu Denpasar Timur.

\section{Penulisan Kata Depan}

Kesalahan penulisan kata depan ditemukan juga pada surat resmi/dinas keluar desa Kesiman Kertalangu Denpasar Timur. Penulisan kata depan yang salah seperti tertera pada contoh kalimat berikut.

1) Terkait hal tersebut diatas, ...

2) Sehubungan dengan hal tersebut diatas ...

Berdasarkan aturan yang dimuat pada Kitab Lengkap EYD, dijelaskan sebagai berikut: kata depan di, ke, dan dari ditulis terpisah dari kata yang mengikutinya, kecuali di dalam gabungan kata yang sudah lazim dianggap sebagai satu kata, seperti kepada, dan daripada. Dengan demikian penulisan yang benar pada data 1) dan 2) di atas, yaitu sebagai berikut.

1a) Terkait hal tersebut di atas, ....

2a) Sehubungan dengan hal tersebut di atas ....

\section{Penulisan kata yang Hiperkorek}

Kata hiperkorek (hypercorrect) berarti terlalu terlalu benar. Di dalam ilmu 
bahasa diartikan 'melampaui batas benar atau tepat sehingga menjadi salah'. Oleh karena itu, jikalau dikatakan bahwa suatu bentuk kata hiperkorek, maka bentuk itu tidak tepat atau salah.

Gejala bahasa hiperkorek selalu menunjukkan sesuatu yang salah. Oleh karena itu, tidak dibenarkan pemakaiannya dalam karya ilmiah. Setelah diteliti pada surat resmi/dinas keluar desa Kesiman Kertalangu Denpasar Timur ditemukan pula kata yang hiperkorek. Beberapa di antaranya dapat dilihat pada contoh kalimat berikut ini.

3) Rekomendasi Ijin Keramaian.

Di dalam kalimat nomor 3) dijumpai pemakaian kata yang hiperkorek, yaitu kata ijin. Kata ijin berasal dari bahasa Arab. Di dalam bahasa Arab huruf /j/ pada kata ijin ditulis dengan huruf dzal (z). Oleh karena kata ijin dipungut dari bahasa Arab dan bentuk aslinya memakai huruf dzal, maka seharusnya kata ijin ditulis izin. Jadi, kata izin adalah kata baku bahasa Indonesia. Dengan demikian, kalimat nomor 3) di atas seharus diubah menjadi kalimat 3a) sebagai berikut.

3a) Rekomendasi izin keramaian.

\section{Pemakaian Kata yang tidak Tepat}

Pemakain kata berarti usaha memilih kata-kata tertentu untuk dapat menyampaikan maksud secara tepat serta sesuai dengan situasi yang dihadapi. Kata yang dipilih secara tepat dan sesuai maksudnya kata yang digunakan menimbulkan gagasan-gagasan atau pengertian-pengertian yang sama antara penulis dengan pembaca serta tidak merusak situasi atau suasana pembaca.

Agar dapat memakai kata dengan tepat, seorang penulis harus menguasai kosa kata yang cukup banyak dan menguasai kaidah-kaidah penggunaan kata tersebut. Oleh karena itu, baik penguasaan kosa kata maupun kaidah penggunaannya sangat penting untuk diketahui agar dapat berhasil memakai kata secara tepat.

Kesalahan pemakaian kata sering terjadi karena penulis kurang mengetahui arti kata secara tepat dan kurang mengetahui bagaimana cara menghubungkan kata dengan kata lain dalam frase, klausa, dan kalimat. Pemakaian kata yang tidak tepat cukup banyak dijumpai dalam surat resmi/dinas keluar desa Kesiman Kertalangu Denpasar Timur. Beberapa di antaranya dapat diperhatikan pada kalimat berikut.

4) Kepada:

Yth.- Bapak Kepala Puskesmas Dentim II di Denpasar

5) Yth,- Bapak Kepala Puskesmas Dentim II di Denpasar

6) Jam : 09.30 Wita

7) ..., maka bersama surat ini kami mengharapkan kehadiran Bapak/Ibu/ Saudara nanti....

8) Tembusan disampaikan kepada Yth:

1. Kepala Dinas Sosial Kota Denpasar

2. Camat Denpasar Timur

3. Ketua BPD Desa Kesimana Kertalangu

4. Kepala Dusun se-Desa Kesiman Kertalangu

5. Arsip 
Pada data 4) di atas ditemukan kesalahan pemakaian kata kepada yang tidak tepat. Sesuai aturan, alamat surat tidak diawali kata kepada karena kata tersebut berfungsi sebagai penghubung intrakalimat yang menyatakan arah. Demikian pula, alamat pengirim tidak didahului kata dari karena kata dari berfungsi sebagai penghubung intrakalimat yang menyatakan asal (E. zaenal Arifin \& Dkk, 1985). Dengan demikian, penulisan alamat yang benar, yaitu sebagai berikut.

4a) Yth. Kepala Puskesmas II di Denpasar

Di dalam surat resmi/dinas keluar desa Kesiman Kertalangu, Denpasar Timur ditemukan juga kesalahan pemakaian kata bapak yang tidak tepat (data 5). Jenis kesalahan ini dapat dilihat pada data nomor 5) di atas. Menurut aturan penulisan alamat surat, jika yang dituju bergelar akademik, seperti Dr., Ir., Drs. Kata sapaan bapak, Ibu, Saudara tidak digunakan. Demikian juga, jika alamat yang dituju memiliki pangkat, seperti sersan atau kapten kata sapaan bapak, Ibu, Saudara tidak digunakan. Selain ketentuan kedua di atas, jika yang dituju adalah jabatan orang, seperti direktur atau kepala instansi tertentu, kata sapaan juga tidak digunakan. Jadi penulisan yang benar dari data 24) di atas dapat diperhatikan berikut ini.

\section{5a) Yth. Kepala Puskesmas II di Denpasar}

Kata jam pada data 6) di atas merupakan kesalahan pemakaian kata yang tidak tepat. Menurut ketentuan kata jam dan pukul (pk.) harus digunakan secara tepat. Kata jam dipakai untuk menunjukkan jangka waktu atau menunjukkan bendanya, sedangkan pukul (pk.) digunakan untuk waktu. Jadi, pemakaian kata yang tepat pada data 6) adalah sebagai berikut.

6a) pk.: 09.30 wita

Pemakaian kata bersama pada data 7) yang tidak tepat ditemukan juga pada surat resmi/dinas keluar desa Kesiman Kertalangu Denpasar Timur. Pemakaian kata bersama terkait dengan lampiran. Kata bersama dipakai jika pada lampiran ada yang dilampirkan. Dalam surat keluar desa Kesiman Kertalangu Denpasar Timur, tidak ada lampirannya, sehingga data 7) di atas menunjukkan kesalahan pemakaian kata bersama. Pemakaian kata yang tepat seharusnya menggnakan kata dengan. Jadi penulisan yang benar dari data 7) di atas dapat diperhatikan berikut ini.

7a) ..., maka dengan surat ini, kami mengharapkan kehadiran Bapak/Ibu/ Saudara nanti ....

Penulisan kata tembusan pada surat resmi/dinas keluar desa Kesiman Kertalangu Kecamatan Denpasar timur masih banyak ditemukan kesalahan seperti pada data 8) di atas. Tembusan bermaksud menyampaikan kepada pembaca, bahwa surat tersebut disampaikan juga kepada pihak lain yang ditembusi karena wajib mengetahui maksud surat tersebut

Aturan penulisan kata tembusan, yaitu ditempatkan pada bagian kiri bawah surat yang lurus dengan penulisan nomor surat di atas. Setelah kata tembusan diikuti tanda titik dua tanpa garis bawah. Jika pihak yang ditembusi surat itu lebih dari satu, nama-nama instansi diberi nomor urut, sesuai dengan status intansinya. 
Vol. 3, No. 1, Januari 2019, 104

Available Online at https://ejournal.warmadewa.ac.id/index.php/kulturistik

DOI: dx.doi.org/10.22225/kulturistik.3.1.954

Di bawah kata tembusan tidak perlu digunakan kata yth. (E. Z. Arifin \& Dkk, 1987). Dengan demikian, penulisan tembusan yang benar, yaitu sebagai berikut.

8a) Tembusan:

1. Kepala Dinas Sosial Kota Denpasar

2. Camat Denpasar Timur

3. Ketua BPD Desa Kesimana Kertalangu

4. Kepala Dusun se-Desa Kesiman Kertalangu

\section{SIMPULAN}

Berdasarkan analisis di atas dapat disimpulkan sebagai berikut. Dalam analisis ini, ditemukan beberapa kesalahan pemakaian kata pada surat resmi/dinas keluar desa Kesiman Kertalangu Denpasar Timur.

Kesalahan pemakaian kata dapat dirinci sebagai berikut: 1) penulisan kata depan semestinya tidak menggunakan tanda hubung, tetapi dalam surat resmi/ dinas keluar desa Kesiman Kertalangu masih ditemukan pemakaian tanda hubung pada penulisan kata depan, 2) penulisan kata yang hiperkorek, terjadi pada kata ijin dan kata mengijinkan, sedangkan menurut kata baku bahasa Indonesia semestinya ditulis dengan kata izin dan mengizinkan, 3) pemakaian kata yang tidak tepat, cukup banyak ditemukan. Misalnya kata kepada pada alamat tujuan seharusnya tanpa kata kepada, pemakaian kata Bapak di depan nama jabatan yang semestinya tanpa kata Bapak, pemakaian kata jam yang menunjukkan waktu,adalah salah yang benar mestinya menggunakan kata pukul/pk., dan pemakaian kata bersama tanpa adanya lampiran atau sesuatu yang menyertai surat itu, mestinya lebih tepat digunakan kata dengan.

\section{DAFTAR PUSTAKA}

Arifin, E. Z., \& Dkk. (1987). Penggunaan Bahasa Indonesia Dalam Surat Dinas. Jakarta: PT. Melton Putra.

Arifin, E. zaenal, \& Dkk. (1985). Cermat Berbahasa Indonesia. Jakarta: PT. Melton Putra.

Hadi, S. (1973). Metodologi research. Yogyakarta: Yayasan Penerbit Fakultas Psikologi Universitas Gajah Mada.

Poerwadarminta, W. J. . (1976). Kamus umum bahasa Indonesia. Jakarta: PN. Balai Pustaka.

Sudaryanto. (1986). Metode linguistik. Yogyakarta: Gadjah Mada University Press.

Sudaryanto. (1993). Metode dan aneka teknik analisis bahasa. Jakarta: Duta Wacana University Press. 